\section{Tutki, lue, kirjoita ja ajattele!}

Hanna Vilkka (2020). Akateemisen lukemisen ja kirjoittamisen opas. Jyväskylä: PS-kustannus. 243 sivua.

TIETO- JA OPPIKIRJAILIJA, yliopisto-opettaja Hanna Vilkka on tehnyt tervetulleen kirjan akateemisen opinnäytteen kirjoittajille ja opinnäytteiden ohjaajille. Teos on lukemaan, kirjoittamaan, ajattelemaan ja keskustelemaan innostava käytännönläheinen käyttö- ja toimintaopas. Se soveltuu oivasti myös tieteellisen kirjoittamisen opetukseen.

Vilkka perustelee oppaan merkitystä sillä, että korkeakoulusta valmistuva tarvitsee hyviä viestintä-, vuorovaikutus- ja yhteistyötaitoja ja kaikkia näitä suullisina, kirjallisina ja digitaalisina taitoina. Opintojen aikana tutuksi tuleva akateeminen luku- ja kirjoitustaito on työkalu, jolla otetaan haltuun analyyttiset ja kriittiset ajattelu- ja ongelmanratkaisutaidot ja lähdekriittinen suhtautuminen.

Lukeminen ja kirjoittaminen ovat mitä suurimmassa määrin toimintaa, ja etenkin akateemisina taitoina niillä voi muuttaa maailmaa. Sivistysyliopiston tehtävänä on varmistaa, että sieltä valmistuneet ovat monilukutaitoisia alansa asiantuntijoita, Vilkka toteaa.

Kirjoittaminen on Vilkan mukaan kokemuksellista toimintaa, jonka avulla ajatellaan refleksiivisesti ja opitaan reflektoiden. Opas auttaa opettelemaan sellaisia lukemisen ja kirjoittamisen työtapoja, jotka ovat hyödyksi paitsi opinnäytettä tehdessä, myös opintojen varhaisemmissa vaiheissa, kuten oppimistehtäviä laatiessa. Vilkka muistuttaa myös lähdekritiikin välttämättömyydestä sekä hyvästä tieteellisestä käytännöstä ja plagi-

Vilkka kirjoittaa Sinikka Viskariin Tieteellisen kirjoittamisen oppaaseen (2009) viitaten: "Akateemisen koulutuksen keskeinen tavoite on se, että valmistuttuasi hallitset ajattelun taidon, kykenet hallitsemaan tietokokonaisuuksia ja tuottamaan niistä merkityksellistä sisältöä selvityksinä, raportteina ja tutkimuksina. Lisäksi tavoite on, että ajattelusta tuottamasi teksti on asiakeskeistä, rakenteellisesti johdonmukaista, täsmällistä, perusteltua ja kriittistä sekä tekstinä yhtenäistä, sidosteista ja kieliopillisesti oikeakielistä."

Niinpä hän jäsentää oppaansa tietosisältöön ja sovellusharjoituksiin. Läpi oppaan on lukuisia, tietosisältöä havainnollistavia esimerkkejä. Harjoitukset ovat pedagogisesti perusteltuja ja käytännössä kandidaatti- ja maisteriopintojen opinnoissa sekä tohtoriopiskelijoiden kirjoituspajoissa testattuja. $\mathrm{Ne}$ kannustavat ajattelemaan itse mutta myös yhdessä vertaisoppijoiden ja opettajan tai ohjaajan kanssa.

\section{TIEDOSTAVASTA LUKEMISESTA TIEDONMUODOSTUKSEEN}

Kirjan aloitusluku käsittelee tiedostavaa lukemista ja kirjoittaoinnin sudenkuopista.

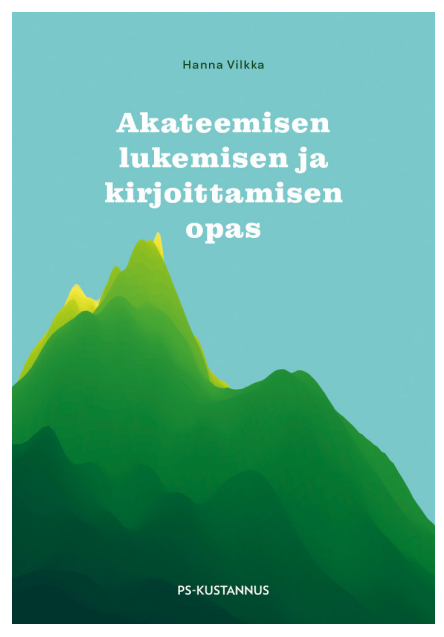

mista sekä kriittistä ja eettistä tiedonmuodostusta. Akateemisen opiskelun vakiotekstilajit essee, luento- ja oppimispäiväkirja ja tutkimussuunnitelma esitellään lyhyesti olennaisilta osiltaan. Aloitusluku luo oppaan tiedollisteoreettisen perustan. Ote on silti oppaan käyttäjän näkökulmasta pragmaattinen. Vilkka kirjoittaa konstailemattomasti ja selkeästi.

Oppaan toinen osa keskittyy itsetuntemukseen, joka on reflektoivassa kirjoittamisessa tärkeää. Kirjoittamista ja lukemista tarkastellaan tunnetodellisuutena ja tunnetyönä, johon kirjoittajan temperamentilla on vaikutuksensa. Sen ansiona on tuore näkökulma niin kirjoittamiseen kuin temperamentin ja oppimisen suhteeseen. Mielenkiintoinen perspektiivi oivalluttaa lukijaa, joka saanee Vilkan tarkastelutavasta herätteitä ja virikkeitä kirjoittajaminänsä kohtaamiseen. Opettajalle ja ohjaajalle osa on näkemyksiä ja praksista tuoreuttavaa luettavaa ja sovellettavaa. 


\section{SIVISTYSYLIOPISTON TEHTÄV ̈̈N $\ddot{A}$ ON TUOTTAA}

MONILUKUTAITOISIA ALANSA ASIANTUNTIJOITA.

\section{PROSESSIKIRJOITTAMISESSA ON SYNERGIAA}

Kolmas osa on käytännönläheisin ja laajin. Se sisältää lukuisia käytännön ohjeita ja vinkkejä akateemisen luku- ja kirjoitustaidon edistämiseksi. Vilkka esittelee prosessikirjottamisen työtavan vaiheineen ja osoittaa, miten siinä yhdistyvät neljä tärkeää asiaa: lukeminen, kirjoittaminen, ajatteleminen ja keskusteleminen. Lukemisen edistäjiksi Vilkka mainitsee eri vaiheiden joustavasti vaihtelevat lukutavat, kuten alun silmäilyn ja jatkovaiheiden syventyvän lukemisen, sekä muistiinpanot, ajankäytön suunnittelun ja mielle- ja käsitekartat. Kirjoittamisen edistäjinä hän esittelee muun muassa vapaan kirjoittamisen, silmukoinnin ja lumihiutaleen, jotka sisältyvät moniin muihinkin kirjoitusoppaisiin. Ei silti tee pahaa nostaa niitä esiin yhä uudelleen.

Harjoitukset vaihtelevat laajuudeltaan nopeista tuntumaa ottavista ja orientoivista vaiheistettuihin tehtäväkokonaisuuksiin, kuten kohdennetun lukemisen ja kirjoittamisen harjoitukseen, jossa ensin luetaan artikkeli ja sitten kirjoitetaan siitä kohdennetusti vaiheittain.
Kolmannen osan lopuksi Vilkka käsittelee kirjoittamisen vertaispalautetyöskentelyä. Esimerkkeinä ovat kirjoituspajat ja vertaispalautteen antaminen ja vastaanottaminen sekä reflektiivinen vertaispalautekeskustelu, joiden soisi yleistyvän opintojaksoilla ja seminaareissa. Taitojen hallintaan vaaditaan jatkuvaa harjoittelua.

TIINA AIRAKSINEN

FM, tieteellisen kirjoittamisen yliopisto-opettaja

kielikeskus, Tampereen yliopisto 